\title{
WSPÓŁCZESNY WIZERUNEK PIELĘGNIARSTWA W OPINII SPOŁECZEŃSTWA
}

\section{CONTEMPORARY IMAGE OF NURSING IN THE SOCIETY'S OPINION}

\author{
Marta Siwek, Grażyna Nowak-Starz \\ Instytut Zdrowia Publicznego \\ Uniwersytet Jana Kochanowskiego w Kielcach
}

DOI: https://doi.org/10.20883/pielpol.2017.66

\section{STRESZCZENIE}

Wprowadzenie. Zawód pielęgniarki jest zawodem o szczególnym charakterze. Wprowadzenie standardów kształcenia wyższego oraz respektowanie uzyskanych praw na rynku pracy we wszystkich krajach Wspólnoty Europejskiej wzmacniają jakość oraz profesjonalizm świadczeń pielęgniarskich.

Cel. Celem badania było określenie wiedzy społeczeństwa na temat funkcjonowania pielęgniarstwa w Polsce oraz poznanie opinii badanych na temat prestiżu oraz zaufania społecznego zawodu pielęgniarki.

Materiał i metody. Badaniem objęto 120 osób, w tym 62 kobiety oraz 58 mężczyzn, zamieszkałych w województwie świętokrzyskim. W badaniu wykorzystano metode sondażu diagnostycznego. Narzędziem badawczym był kwestionariusz ankiety własnego autorstwa, składający się z 26 pytań zamkniętych. Analizę statystyczną przeprowadzono za pomocą pakietu IBM Statistics 23. Z jego użyciem wykonano szereg testów $\chi^{2}$ niezależności. Za poziom istotności w niniejszym badaniu uznano $p<0,05$.

Wyniki. Prestiż zawodowy pielęgniarek wzrasta wraz z wiekiem badanych. Badani wskazują, że współczesna pielęgniarka to osoba, która rzetelnie oraz dokładnie wykonuje obowiązki zawodowe oraz systematycznie wzbogaca wiedzę. Zaufanie społeczne wobec pielęgniarek oceniane jest na poziomie wysokim. Lepszą wiedzę na temat sytuacji demograficznej pielęgniarek prezentują osoby młode, do 40. roku życia.

Wnioski. Należy dążyć do intensyfikacji działań na rzecz rozwoju profesjonalizmu, wzmacniając $w$ ten sposób pozycję zawodową oraz zaufanie społeczne pielęgniarek, szczególnie wśród młodego społeczeństwa. Wiedza społeczeństwa na temat aktualnej sytuacji demograficznej pielęgniarek w Polsce oraz ich kompetencji zawodowych i społecznych wymaga systematycznej aktualizacji.

SŁOWA KLUCZOWE: wizerunek, pielęgniarka, prestiż zawodowy.

\section{Wprowadzenie}

W Polsce pielęgniarki stanowią jedną z najliczniejszych grup zawodowych. Z przeprowadzonych badań CBOS (Centrum Badania Opinii Społecznej) na temat hierarchii prestiżu profesji zawodowych wynika, iż 78\% społeczeństwa darzy pielęgniarki wysokim zaufaniem społecznym [1].

Zawód pielęgniarki jest zawodem o szczególnym charakterze. Pielęgniarki narażone są na różnorakie

\begin{abstract}
Introduction. Profession of a nurse is the one having a particular character. Introducing the standards of tertiary education, and also respecting the rights acquired in the labour market, in all the countries of the European Community, raise the quality, and also professionalism, of nursing services.

Aim. The objective of the study was to determine society's knowledge of the functioning of the nursing profession in Poland, its prestige, and also public trust.

Material and methods. The study involved 120 individuals (62 females and 58 males), living in Świętokrzyskie Voivodeship. In the study, the diagnostic survey method was used. The research tool was a survey questionnaire developed by the author, and consisting of 26 multiple choice questions. Statistical analysis was conducted with the use of the IBM Statistics 23 package, by means of which a number of the $\div 2$ tests for independence were performed. The adopted significance level in this study amounted to $p<0.05$.

Results. The older age group is studied, the more positively the professional prestige of nurses is assessed. The studied indicate that a contemporary nurse is a person who reliably, and also carefully, performs her professional duties, and also methodically develops her expertise. Public trust towards nurses is assessed as high. Young people (up to the age of 40 ) are more knowledgeable in terms of the demographical situation of nurses.

Conclusions. Efforts should be made to intensify actions aiming at the development of professionalism, thus strengthening the professional status of, and social trust in, nurses, in particular among young people. Society's knowledge of the current demographical situation of nurses in Poland, and also their professional and social competences, needs to be updated methodically.
\end{abstract}

KEYWORDS: image, nurse, professional prestige. 
sprawiają, że zawód ten staje się mało atrakcyjny dla młodego społeczeństwa [2].

Jest to szczególnie niebezpieczne ze względu na niekorzystną sytuację demograficzną wśród polskich pielęgniarek. Z raportu Naczelnej Rady Pielęgniarek i Położnych wynika, że średni wiek pielęgniarki pracującej w Polsce wynosi 48,43 roku i sytuacja ta nie gwarantuje naturalnej zastępowalności pokoleniowej w zawodzie [2].

W warunkach postępu cywilizacyjnego wzrasta lista czynników, według których społeczeństwo dokonuje oceny jakości pracy poszczególnych zawodów, w tym także pielęgniarek. Ustawiczny, ciągły rozwój pielęgniarstwa poszerza wachlarz kompetencji społecznych pielęgniarki, które świadczy na rzecz budowania dobrostanu społeczeństwa. Zmiany w funkcjonowaniu współczesnego pielęgniarstwa w Polsce wynikają przede wszystkim z transformacji w sektorze edukacji. Wprowadzenie standardów kształcenia wyższego oraz respektowanie uzyskanych praw na rynku pracy we wszystkich krajach Wspólnoty Europejskiej wzmacniają jakość oraz profesjonalizm świadczeń pielęgniarskich.

Zmiany jakościowe, które dokonują się w formach czy metodach doskonalenia zawodowego pielęgniarek, wymuszają podjęcie badań na temat aktualnego wizerunku oraz zaufania społecznego zawodu pielęgniarki w Polsce.

Celem badania było określenie wiedzy społeczeństwa na temat funkcjonowania pielęgniarstwa w Polsce oraz poznanie opinii badanych na temat prestiżu oraz zaufania społecznego zawodu pielęgniarki.

\section{Materiał i metody}

Badaniem objęto 120 osób, w tym 62 kobiety oraz 58 mężczyzn, zamieszkałych w województwie świętokrzyskim. Badania zostały zrealizowane w okresie styczeń - marzec 2016 roku. Pierwszym etapem badań było dobranie w sposób losowy grupy badanych. W kolejnym etapie badań respondenci zostali zapoznani z ankietą oraz poproszeni o jej dokładne wypełnienie na podstawie własnej opinii oraz wiedzy związanej z funkcjonowaniem pielęgniarstwa w Polsce. Dane dotyczące wieku oraz płci respondentów przedstawiono w tabeli 1. W grupie zarówno kobiet, jak i mężczyzn najwyższy odsetek badanych stanowiły osoby młode do 40 . roku życia (50\% badanych). Grupę 41\% stanowiły osoby z wykształceniem wyższym. W badanej populacji było 17\% osób z wykształceniem średnim. Najliczniejszą grupą badanych wśród kobiet i mężczyzn były osoby mieszkające na terenie miasta Kielce (59\%).

W badaniu wykorzystano metodę sondażu diagnostycznego. Narzędziem badawczym był kwestionariusz ankiety własnego autorstwa. Narzędzie to umożliwiło ocenę trzech elementów, które charakteryzują współ- czesny wizerunek pielęgniarki. Ankieta składała się z trzech zestawów pytań, dzięki którym badani ocenili prestiż zawodowy pielęgniarek (część I), zaufanie społeczne (część II) oraz posiadaną wiedzę (część III) na temat funkcjonowania pielęgniarek w Polsce.

W celu oceny prestiżu zawodowego pielęgniarek, zaufania społecznego oraz wiedzy na temat funkcjonowania pielęgniarstwa w Polsce w zależności od wieku oraz płci badanych przeprowadzono analizę statystyczną. Do tego celu wykorzystano pakiet IBM Statistics 23. Z jego użyciem wykonano szereg testów $\chi^{2}$ niezależności. Za poziom istotności w niniejszym badaniu uznano $p<0,05$.

Tabela 1. Charakterystyka grupy badawczej Table 1. The profile of the studied group

\begin{tabular}{|c|c|c|c|c|c|c|c|c|}
\hline \multirow{2}{*}{$\begin{array}{l}\text { Lp./ } \\
\text { No. }\end{array}$} & \multirow{2}{*}{\multicolumn{2}{|c|}{ Analizowane zmienne/Factors }} & \multicolumn{2}{|c|}{$\begin{array}{l}\text { Kobiety/ } \\
\text { Female }\end{array}$} & \multicolumn{2}{|c|}{$\begin{array}{c}\text { Mężczyźni/ } \\
\text { Male }\end{array}$} & \multicolumn{2}{|c|}{$\begin{array}{c}\text { Razem/ } \\
\text { Total }\end{array}$} \\
\hline & & & $\mathrm{n}$ & $\%$ & $n$ & $\%$ & $\mathrm{n}$ & $\%$ \\
\hline 1. & Płeć/Sex & & 62 & $52 \%$ & 58 & $48 \%$ & 120 & 1 \\
\hline \multirow{6}{*}{2} & \multirow{6}{*}{ Wiek/Age } & $\leqslant 30$ & 23 & $37 \%$ & 15 & $26 \%$ & 38 & $32 \%$ \\
\hline & & $31-40$ & 10 & $16 \%$ & 12 & $21 \%$ & 22 & $18 \%$ \\
\hline & & $41-50$ & 10 & $16 \%$ & 11 & $19 \%$ & 21 & $18 \%$ \\
\hline & & $51-60$ & 10 & $16 \%$ & 10 & $17 \%$ & 20 & $17 \%$ \\
\hline & & $>60$ & 9 & $15 \%$ & 10 & $17 \%$ & 19 & $16 \%$ \\
\hline & & Razem/Total & 62 & $100 \%$ & 58 & $100 \%$ & 120 & $100 \%$ \\
\hline \multirow{5}{*}{3.} & \multirow{5}{*}{$\begin{array}{c}\text { Wykształcenie/ } \\
\text { Education }\end{array}$} & $\begin{array}{c}\text { podstawowe/ } \\
\text { primary }\end{array}$ & 4 & $6 \%$ & 5 & $9 \%$ & 9 & $8 \%$ \\
\hline & & $\begin{array}{c}\text { średnie/ } \\
\text { secondary }\end{array}$ & 11 & $18 \%$ & 10 & $17 \%$ & 21 & $18 \%$ \\
\hline & & $\begin{array}{l}\text { średnie zawo- } \\
\text { dowe/secondary } \\
\text { vocational }\end{array}$ & 20 & $32 \%$ & 21 & $36 \%$ & 41 & $34 \%$ \\
\hline & & wyższe/higher & 27 & $44 \%$ & 22 & $38 \%$ & 49 & $41 \%$ \\
\hline & & Razem/Total & 62 & $100 \%$ & 58 & $100 \%$ & 120 & $100 \%$ \\
\hline \multirow{3}{*}{4.} & \multirow{3}{*}{$\begin{array}{l}\text { Miejsce za- } \\
\text { mieszkania/ } \\
\text { Place of living }\end{array}$} & wieś/village & 28 & $45 \%$ & 21 & $36 \%$ & 49 & $41 \%$ \\
\hline & & miasto/city & 34 & $55 \%$ & 37 & $64 \%$ & 71 & $59 \%$ \\
\hline & & Razem/Total & 62 & $100 \%$ & 58 & $100 \%$ & 120 & $100 \%$ \\
\hline
\end{tabular}

Źródło: badania własne

Source: author's own materials

\section{Wyniki}

W podjętych badaniach wykazano zależność między oceną pozycji zawodowej pielęgniarek a wiekiem oraz płcią badanych. Wyniki okazały się być istotne statystycznie zarówno w grupie kobiet $-\chi^{2}(12)=29,43$; $p<0,01$, jak i w grupie mężczyzn $-\chi^{2}(12)=22,74$; $p<0,05$. Pozycja zawodowa pielęgniarek była lepiej oceniona przez kobiety i mężczyzn po 40. roku życia. Niskie oceny pozycji zawodowej pielęgniarek dotyczą młodej części badanej grupy i częściej pojawiają się w grupie mężczyzn (Rycina 1). Na pytanie: „W jakim stopniu prestiż zawodowy pielęgniarek w Polsce zmienił się w ciągu ostatnich 10 lat?” 45\% kobiet oraz 36\% mężczyzn wskazało, iż w ciągu 10 lat prestiż ten wzrósł bądź utrzymuje się na tym samym poziomie. 
W badaniu dokonano także analizy czynników, które wpływają na poprawę wizerunku zawodu pielęgniarek w Polsce. Zarówno kobiety, jak i mężczyźni uznali, iż podnoszenie kwalifikacji zawodowych jest najważniejszym elementem, mogącym wzmacniać wizerunek zawodowy pielęgniarek. Blisko 80\% kobiet powyżej 60 . roku życia uważa, iż drugim czynnikiem budującym wizerunek pielęgniarek jest doświadczenie zawodowe nabywane wraz ze stażem pracy (Rycina 2).

Wśród instytucji, które w opinii badanych powinny wzmacniać wartość pielęgniarstwa na arenie krajowej oraz międzynarodowej, jest związek zawodowy pielęgniarek i położnych (45\% kobiet oraz 52\% mężczyzn). Kolejną instytucją powołaną do budowania dobrego wizerunku i zaufania jest według badanych rząd (37\% ogółu badanych). Wśród instytucji, które w opinii badanych w najmniejszym stopniu wpływają na budowanie wizerunku pielęgniarek, respondenci wskazali media (5\% badanych) oraz pacjentów ( $8 \%$ badanych).

W dobie niekorzystnych sytuacji, które obecnie dokonują się w obszarze pielęgniarstwa, zbadano także opinie badanych na temat odbywających się w naszym kraju manifestacji oraz protestów pielęgniarek. Na pytanie: „Jak ocenia Pani/Pan protesty i manifestacje pielęgniarek w Polsce w sprawie wzrostu wynagrodzenia oraz ustalenia prawidłowych norm zatrudnienia na oddziałach szpitalnych?" aż 55\% kobiet oraz 43\% mężczyzn wyraziło akceptację i zrozumienie do tego rodzaju działań. Zarówno kobiety (23\%), jak i mężczyźni (31\%) wskazali, że protesty ukazują aktualne problemy tego zawodu i dążenia do wprowadzenia zmian, które poprawią atrakcyjność tego zawodu wśród młodego społeczeństwa.

W badaniu dokonano także oceny zaufania społecznego wobec pielęgniarek. W danych zawartych na ryci- nie 3 wynika, że zaufanie społeczne wobec pielęgniarek jest wyższe wśród kobiet po 30. roku życia (39\%). W grupie mężczyzn w każdej grupie wiekowej ponad $50 \%$ badanych wykazało zaufanie społeczne wobec pielęgniarek na wysokim poziomie.

W kolejnym etapie badań dokonano oceny tych cech pielęgniarek, które w opinii respondentów wpływają na budowanie relacji pielęgniarka - pacjent. Według kobiet zaufanie $w$ relacjach $\mathrm{z}$ pielęgniarką jest wzmacniane, kiedy wykazuje ona postawę cierpliwości w kontaktach z pacjentem (77\%). Mężczyźni zaś wskazują, iż sumienne i dokładne wykonywanie powierzonych obowiązków zawodowych przez pielęgniarkę jest istotnym elementem budującym relację z pacjentem (72\%). Uczciwość (81\% ogółu badanych), umiejętność słuchania (71\% ogółu badanych) oraz inteligencja (69\% ogółu badanych) to cechy, które w opinii respondentów nie mają istotnego wpływu na tworzenie relacji pielęgniarki z pacjentem.

Biorąc pod uwage wszelkie zmiany i transformacje, które towarzyszyły pielęgniarstwu na przestrzeni lat, zbadano także, czym według badanych charakteryzuje się współczesna pielęgniarka w Polsce. Z przeprowadzonej analizy wynika, iż grupa zarówno kobiet, jak i mężczyzn uważa, iż współczesna pielęgniarka to osoba, która rzetelnie i dokładnie wykonuje swoje obowiązki zawodowe (42\% kobiet oraz mężczyzn). Badani wskazali również, że duże znaczenie w postrzeganiu współczesnej pielęgniarki ma jej gotowość do systematycznego zwiększania wiedzy (ponad 33\% kobiet i mężczyzn), a tym samym profesjonalizmu zawodowego. Ponad 30\% kobiet oraz 40\% mężczyzn w wieku powyżej 60 lat opisuje pielęgniarkę jako osobę moralnie odpowiedzialną za zdrowie i życie pacjentów (Rycina 4).

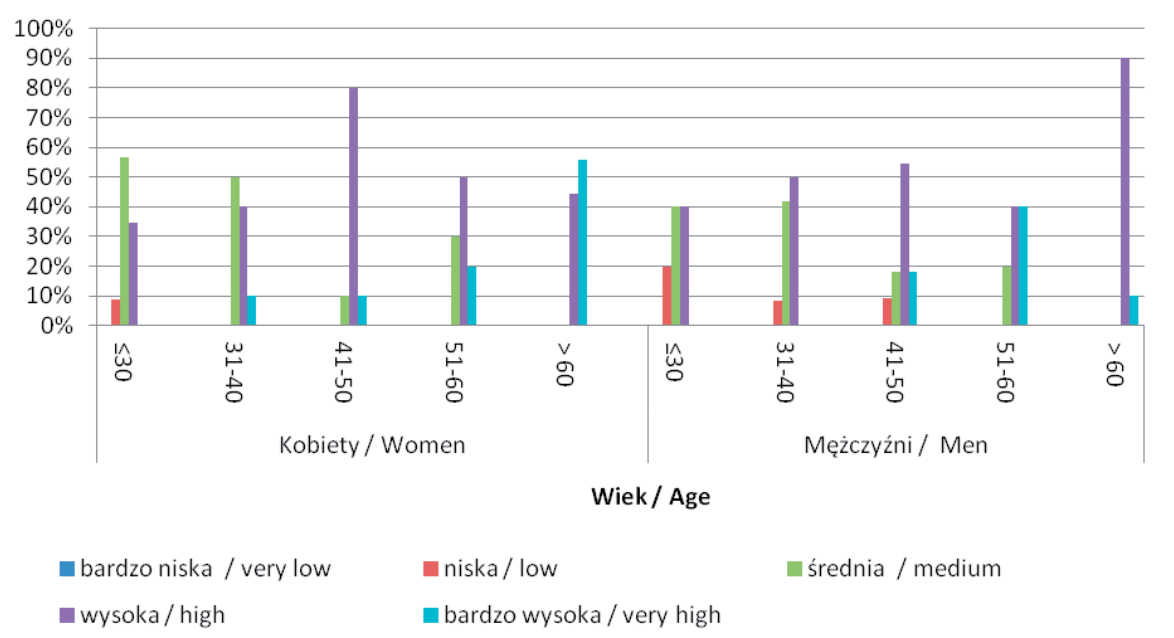

Rycina 1. Ocena pozycji zawodowej pielęgniarek w zależności od płci i wieku badanych Figure 1. The assessment of the professional status of nurses, depending upon the sex and age of the studied Źródło: badania własne Source: author's own materials 


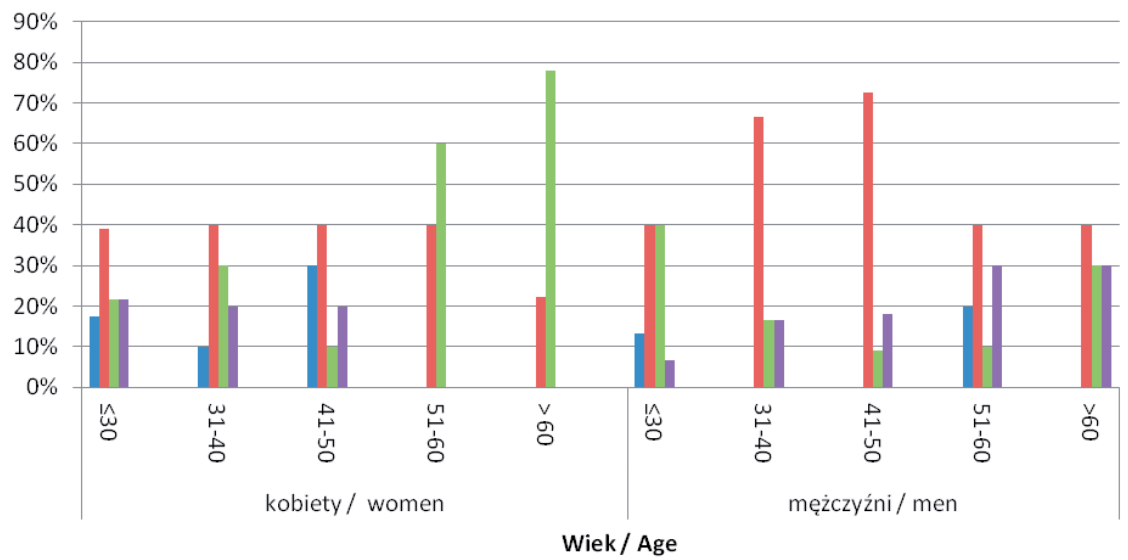

n poziom wykształcenia / level of education

a podnoszenie kwalifikacji / raising qualifications

nstaż pracy / length of service

— kompetencje pielęgniarek w zakresie wykonywania świadczeń zdrowotnych / nurses' competences in the scope of providing medical services

Rycina 2. Ocena czynników wpływających na poprawę wizerunku pielęgniarek Figure 2. The assessment of factors exerting influence on improvement in the image of nurses Źródło: badania własne

Source: author's own materials

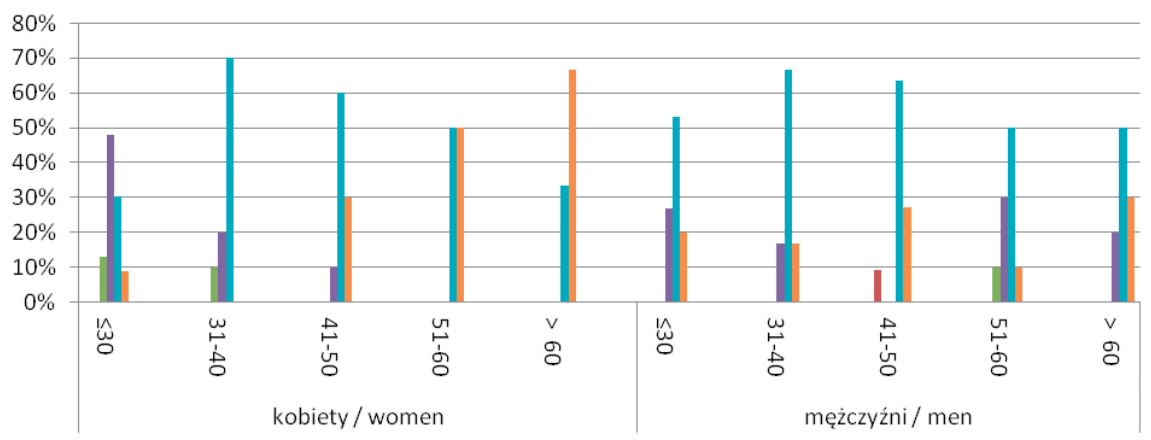

Wiek / Age

E nie mam zdania / I have no opinion

niski / low

wysoki / high bardzo niski / very low

úredni / medium

- bardzo wysoki / very high

Rycina 3. Poziom zaufania społecznego do pielęgniarek Figure 3. The level of public trust in nurses

Źródło: badania własne

Source: author's own materials 


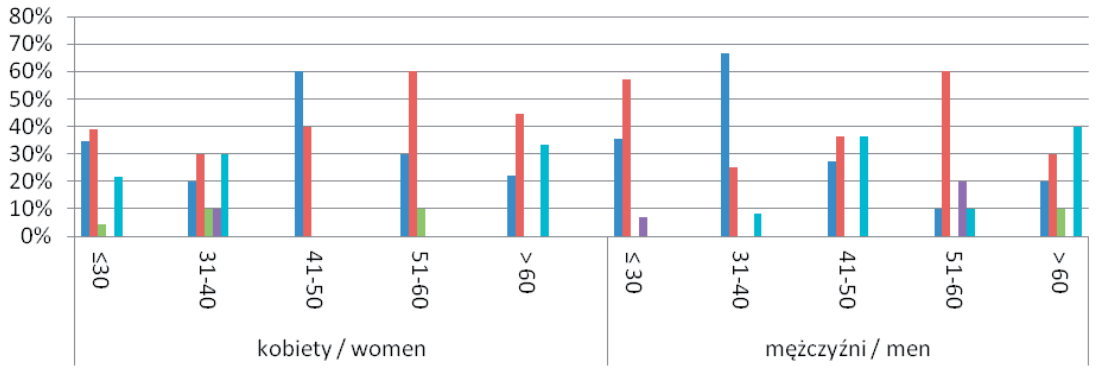

Wiek / Age

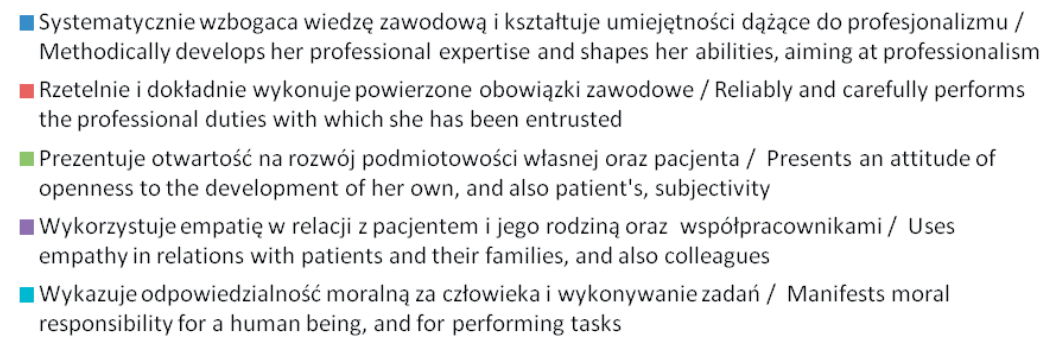

Rycina 4. Kompetencje społeczne charakteryzujące pielęgniarkę XXI wieku Figure 4. The social competences characterizing the nurse of the $21^{\text {st }}$ century

Źródło: badania własne

Source: author's own materials

W badaniach przeanalizowano również, jaką wiedzę mają badani na temat funkcjonowania pielęgniarstwa w Polsce. Na pytanie: „Jaki jest średni wiek pielęgniarek pracujących w Polsce?" uzyskano wyniki istotnie statystycznie zarówno $w$ grupie kobiet $\left(\chi^{2}(12)=36,16\right.$; $\mathrm{p}<0,001)$, jak i w grupie mężczyzn $\left(\chi^{2}(12)=29,20\right.$; $\mathrm{p}<0,01)$. Lepszą wiedzę na temat sytuacji demograficznej w polskim pielęgniarstwie prezentowały młode kobiety oraz młodzi mężczyźni do 40. roku życia. W pozostałych grupach wiekowych wykazano duże rozpiętości w udzielanych odpowiedziach. Oznaczać to może konieczność edukowania społeczeństwa w zakresie demografii polskiego pielęgniarstwa (Rycina 5).

W celu określenia wiedzy badanych na temat funkcjonowania pielęgniarstwa w Polsce dokonano analizy związku pomiędzy płcią i wiekiem a odpowiedzią udzieIoną na pytanie dotyczące czynności zawodowych, do których uprawniona jest pielęgniarka w Polsce. Zarówno kobiety $(97 \%)$, jak i mężczyźni $(90 \%)$ postrzegali pielęgniarkę w roli edukatora oraz promotora zdrowia. Według badanych pielęgniarka to także osoba, która jest uprawniona do rozpoznawania problemów pielęgnacyjnych pacjenta oraz planowania i realizowania opieki pielęgnacyjnej (93\% ogółu badanych). Niepokojący jest fakt, iż blisko 44\% kobiet oraz 34\% mężczyzn poniżej 30. roku życia uważa, iż pielęgniarka w Polsce nie ma uprawnień do samodzielnego udzielania w określonym zakresie świadczeń zapobiegawczych, diagnostycznych, leczniczych, rehabilitacyjnych oraz medycznych czynności ratunkowych. Blisko $40 \%$ kobiet oraz prawie $42 \%$ mężczyzn w wieku 31-40 lat wskazuje na brak uprawnień pielęgniarek do prowadzenia działalności naukowo-badawczej w dziedzinie nauk o zdrowiu. Około 40\% mężczyzn w wieku 51-60 lat wskazuje na brak uprawnień pielęgniarek do nauczania zawodu pielęgniarki na uczelni wyższej.

Sami badani ocenili swoją wiedzę na temat funkcjonowania pielęgniarstwa na poziomie średnim (50\% ogółu badanych) oraz dobrym (33\% ogółu badanych) (Rycina 6). Niski poziom wiedzy częściej deklarują mężczyźni (40\% w wieku $51-60$ lat oraz 30\% powyżej 60. roku życia). 


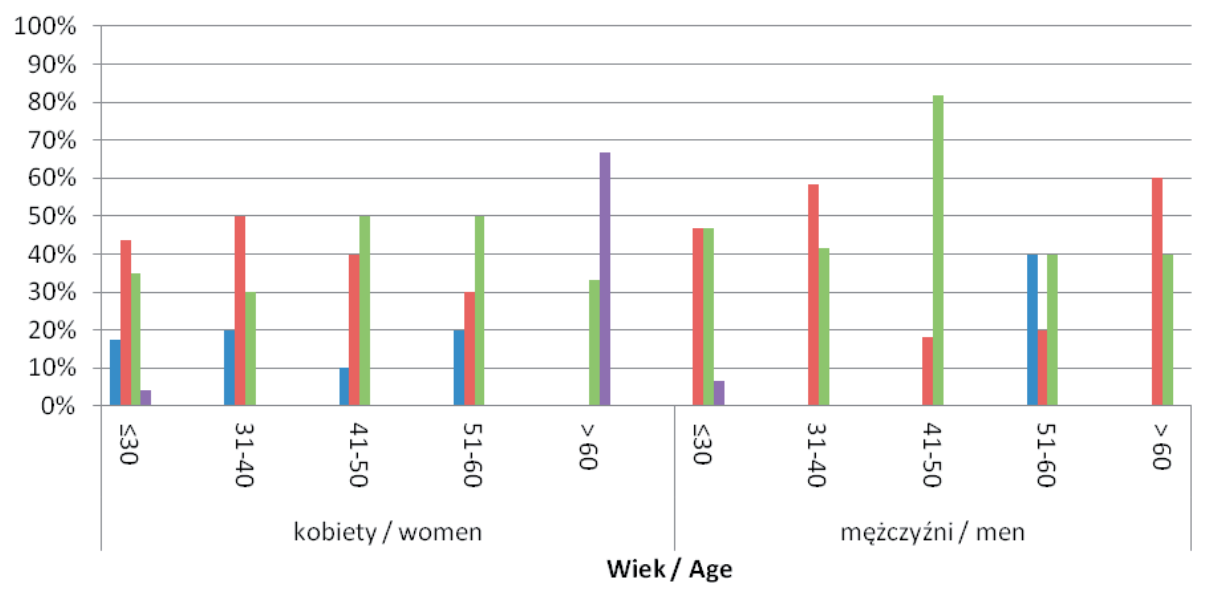

- 30-40

$41-50$

51-60

a $>60$

Rycina 5. Wiedza respondentów na temat średniego wieku pielęgniarki pracującej w Polsce Figure 5. The mean age of a professionally-active nurse in the opinion of the studied

Źródło: badania własne

Source: author's own materials

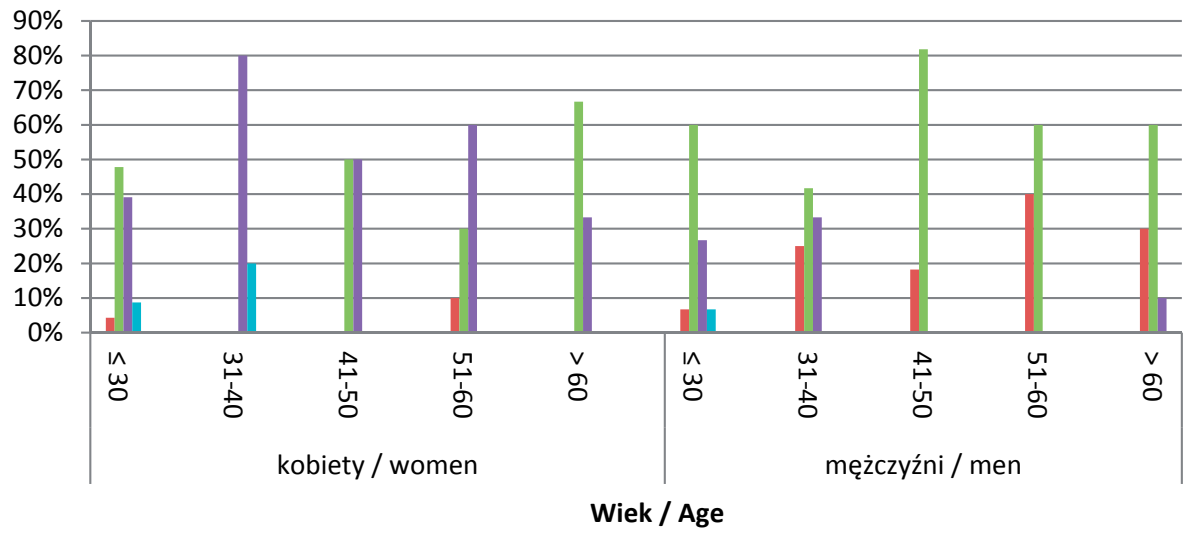
bardzo niski / vey low
niski / low
średni / medium
wysoki / high
bardzo wysoki / very high

Rycina 6. Samoocena poziomu wiedzy badanych na temat funkcjonowania pielęgniarstwa w Polsce

Figure 6. The self-assessment of the respondents' level of knowledge concerning the functioning of the nursing profession in Poland

Źródło: badania własne

Source: author's own materials 


\section{Dyskusja}

Wyniki przeprowadzonych badań wskazują, iż zawód pielęgniarki jest zawodem mało atrakcyjnym szczególnie dla młodego społeczeństwa. Badani deklarowali wysoki poziom zaufania społecznego wobec pielęgniarek oraz wskazali, iż cierpliwość w kontaktach oraz sumienność budują zaufanie w relacji pielęgniarka - pacjent. Lepszy poziom wiedzy na temat funkcjonowania pielęgniarstwa w Polsce prezentują kobiety oraz mężczyźni do 40. roku życia.

Wyniki badań własnych potwierdzają wyższy poziom zaufania wobec pielęgniarek w grupie mężczyzn, co znajduje potwierdzenie w badaniach Stachoń i Rybki. Autorki te zbadały opinie na temat zaufania wobec pielęgniarek, które lepiej zostały ocenione przez mężczyzn oraz osoby w wieku 31-50 lat [3]. Analiza badań własnych dowodzi, iż zarówno kobiety, jak i mężczyźni wysoko oceniają prestiż zawodowy pielęgniarek. W badaniach Mędrzyckiej-Dąbrowkiej i wsp. na pytanie dotyczące wizerunku pielęgniarek w społeczeństwie ponad połowa kobiet $(50,8 \%)$ oraz część mężczyzn $(46,2 \%)$ wskazała, iż zawód pielęgniarki jest zawodem szczególnego zaufania oraz szacunku społecznego [4].

Zawód pielęgniarki w Polsce jest coraz lepiej oceniany wśród społeczeństwa. Badania CBOS przeprowadzone w Polsce w 1999 roku (po raz pierwszy wpisano zawód pielęgniarki na listę sondażową) wykazały, że $57 \%$ badanych deklarowało duże poważenie wobec tego zawodu [5]. Kolejna analiza prestiżu profesji zawodowych przeprowadzona 10 lat później potwierdziła wzrost uznania dla zawodu pielęgniarki [6]. Na podstawie powyższych wyników należy stwierdzić, iż pozycja zawodowa pielęgniarek przeszła pozytywną przemianę. Prestiż tego zawodu, oceniony na miejscu szóstym w 1999 roku, osiągnął miejsce czwarte w 2009 roku, wyprzedzając zawód lekarza. Sobczak i Kamińska w swych badaniach, których celem było określenie poziomu prestiżu zawodowego pielęgniarek, wskazały, iż według badanych pozycja zawodowa pielęgniarek w ciągu ostatnich 20 lat nie uległa zmianie i jest oceniana jako średnia [7]. Wyniki badań własnych ukazują, iż zawód pielęgniarki w ocenie młodszych respondentów ma niższy prestiż, co znajduje potwierdzenie w badaniach Mędrzyckiej-Dąbrowskiej i wsp. W przytoczonych badaniach poddano ocenie prestiż zawodowy pielęgniarek, który młodzi badani ocenili na poziomie średnim [4]. W badaniu tym zapytano także młodzież, czy wiąże ona swoją przyszłość z zawodem pielęgniarki. Większość badanych odpowiedziała negatywnie, uzasadniając to niskim wynagrodzeniem, dużą odpowiedzialnością oraz specyfiką i charakterem wykonywania tego zawodu [4].
Analiza badań ilościowych potwierdza wyniki badań własnych na temat czynników, które w opinii badanych wzmacniają wizerunek pielęgniarek. W badaniach Sobczak i Kamińskiej respondenci wskazali, iż wizerunek pielęgniarstwa wzmacniany jest poprzez ustawiczne podnoszenie kwalifikacji zawodowych [7]. Odmienne zdanie w tej kwestii mają same pielęgniarki. Według nich pozycja zawodowa wzmacniana jest dzięki takim czynnikom, jak samodzielność zawodowa, a nie - jak sądzi większość badanego społeczeństwa kwalifikacje zawodowe czy wynagrodzenie [8]. Analiza czynników mających wpływ na budowanie wizerunku pielęgniarek wykazała, iż poziom wykształcenia oraz doskonalenia zawodowe i profesjonalizm pozytywnie wpływają na kreowanie wizerunku pielęgniarek [9]. W badaniach Mroczek i wsp. nad oczekiwaniami pacjentów względem personelu pielęgniarskiego $27 \%$ respondentów wskazało, iż profesjonalizm zawodowy oraz rzetelność wykonywania obowiązków wzmacniają wizerunek pielęgniarek [10]. Również w badaniach własnych respondenci wskazali, iż istotne znaczenie dla budowania wizerunku pielęgniarek mają takie czynniki, jak podnoszenie kwalifikacji zawodowych oraz doświadczenie i profesjonalizm zawodowy.

Zgodnie z opinią badanych zawód ten cechuje się dużą odpowiedzialnością moralną wobec pacjentów, którzy pragną widzieć pielęgniarkę jako osobę przygotowaną do roli opiekuńczo-wychowawczej [11]. Wyniki badań Grabskiej i Stefańskiej potwierdzają znaczenie pewnych cech w budowaniu oraz umacnianiu zaufania w relacji pielęgniarka - pacjent [12]. W opinii badanych do najważniejszych z nich należą: staranność oraz dokładność wykonywanych zabiegów oraz cierpliwość i wyrozumiałość w kontaktach z pacjentami [12]. Kapała i wsp. w swych badaniach wykazali, iż pacjenci najczęściej oczekują od pielęgniarek dużych zdolności manualnych oraz życzliwości i troskliwości [13]. Również Krajewska-Kułak i wsp. w swych badaniach przeprowadzonych w grupie studentek pielęgniarstwa wskazali na znaczenie takich cech, jak chęć pomagania, cierpliwość oraz sumienność, które ułatwiają tworzenie właściwych relacji w opiece nad pacjentem [14]. Badania Wańkowicz i wsp. mające na celu ocenę wizerunku pielęgniarki w oczach rodziców hospitalizowanych dzieci wykazały, iż idealny wizerunek pielęgniarki tworzą takie cechy, jak uśmiech, spokój oraz uprzejmość [15]. Wyniki badań własnych potwierdzają znaczenie takich czynników, jak cierpliwość w kontaktach z pacjentem oraz rzetelność i dokładność podczas wykonywania czynności pielęgniarskich, które budują relację pielęgniarka - pacjent.

Dokonując w badaniach własnych charakterystyki współczesnej pielęgniarki, uzyskano wyniki, które opisują pielęgniarkę jako osobę, która rzetelnie wykonu- 
je swe obowiązki oraz systematycznie zwiększa swą wiedzę zawodową, dążąc do profesjonalizmu. Według Grabskiej i Stefańskiej model współczesnej pielęgniarki w dużej mierze zależy od kondycji systemu ochrony zdrowia, a także od posiadanych przez pielęgniarkę specjalizacji [12]. Badania Kojder i Zarzyckiej dowodzą, iż pielęgniarki są lepiej oceniane przez osoby, które mają z nimi kontakt i korzystają z ich świadczeń pielęgniarskich [16]. Również Leszczyńska i wsp. w swych badaniach oceniających jakość usług pielęgniarskich w podstawowej opiece zdrowotnej zauważyli, iż opinia pacjentów na temat pielęgniarek jest ściśle połączona z oceną jakości świadczonych usług pielęgniarskich [17].

Jak wynika z badań własnych, wiedza respondentów związana z funkcjonowaniem pielęgniarstwa w Polsce oraz sytuacją demograficzną pielęgniarek polskich jest niewystarczająca. Dokonując analizy fachowej oraz dostępnej literatury związanej z tematyką pracy, nie odnaleziono wyników badań, które oceniałyby wiedzę społeczeństwa na temat funkcjonowania pielęgniarstwa w Polsce. Obszar ten z uwagi na transformacje, które zaszły w systemie kształcenia, oraz nabywanie nowych uprawnień przez pielęgniarki wymaga obserwacji i kontynuacji badań w tym zakresie.

\section{Wnioski}

1. Należy dążyć do intensyfikacji działań na rzecz budowania prestiżu zawodowego oraz zaufania społecznego pielęgniarek, a tym samym poprawy atrakcyjności tego zawodu, szczególnie wśród młodego społeczeństwa.

2. Z uwagi na niewystarczającą wiedzę społeczeństwa związaną z funkcjonowaniem pielęgniarstwa w Polsce należy podejmować działania edukacyjne i promujące działalność pielęgniarek w roli kompetentnego opiekuna, promotora zdrowia, naukowca, lidera, decydenta, a przede wszystkim profesjonalisty.

3. Niska wiedza społeczeństwa na temat aktualnej sytuacji demograficznej pielęgniarek w Polsce i zagrożeń z tą sytuacją związanych wymaga podjęcia działań służących aktualizowaniu wiedzy w tym zakresie.

\section{Piśmiennictwo}

1. (Dostępne w Internecie:) http://www.cbos.pl/SPISKOM.POL/2013/K_164_13. (data dostępu: 15.06.2016).

2. Zabezpieczanie społeczeństwa polskiego w świadczenia pielęgniarek i położnych. Raport. Warszawa: Naczelna Rada Pielęgniarek i Położnych; 2015, http://arch.nipip.pl/attachments/ article/3368/Raport_2015_NIPiP (data dostępu: 15.06.2016).

3. Stachoń K, Rybka M. Pielęgniarstwo jako zawód zaufania publicznego w opinii pacjentów. Innowacje w Pielęgniarstwie i Naukach o Zdrowiu. 2016; 4(1): 26-31.
4. Mędrzycka-Dąbrowska W, Bąkowska G, Kwiecień-Jaguś K, Gaworska-Krzemińska A. Postrzeganie zawodu pielęgniarki przez młodzież szkół ponadgimnazjalnych jako wybór przyszłego zawodu - doniesienia wstępne. Probl Piel. 2012; 20(2): 192-200.

5. Falkowska M. Prestiż zawodów. Komunikat z badań. Warszawa: Centrum Badania Opinii Społecznej; 1999.

6. Feliksiak M. Prestiż zawodów. Komunikat z badań. Warszawa: Centrum Badania Opinii Społecznej; 2009.

7. Sobczak M, Kamińska B. Poziom prestiżu zawodowego pielęgniarek w opinii wybranych grup. Probl Piel. 2012; 20(2): 218-222.

8. Kot-Doniec B, Kiryłowicz E. Pozycja zawodowa pielęgniarek i położnych w ich własnej opinii. Mag Piel Położ. 2010; 5: 8-9.

9. Centrum Kształcenia Podyplomowego Pielęgniarek i Położnych. Pozycja zawodowa pielęgniarek, położnych w opinii przedstawicieli innych zawodów medycznych, http://www. ckppip.edu.pl/doki/pozycia_zawody_med.doc (data dostępu: 15.06.2016).

10. Mroczek B, Parakiewicz A, Grochans E et al. Wizerunek społeczny zawodu pielęgniarki. Fam Med Prim Care Rev. 2012; 14(1): 4-47.

11. Ślusarska B, Zarzycka D, Czerkida M. Postrzeganie przyszłości determinowane doświadczeniami kandydatów do zawodu pielęgniarki. Zdr Publ. 2005; 115: 57-61.

12. Grabska K, Stefańska W. Sylwetka zawodowa pielęgniarki w opinii pacjentów. Probl Piel. 2009; 17(1): 8-12.

13. Kapała W, Chudziński S, Hyrcza S. Oczekiwania pacjentów hospitalizowanych na oddziałach zabiegowych wobec personelu pielęgniarskiego. Piel Chir Angiol. 2008; 1: 12-18.

14. Krajewska-Kułak E, Van Damme-Ostapowicz K, Bielemuk A et al. Samoocena postrzegania zawodu pielęgniarki oraz zdolności rozumienia empatycznego innych ludzi przez studentów pielęgniarstwa. Probl Piel. 2010; 1(1): 1-10.

15. Wańkowicz A, Golubka P, Dłuski D. The professional image of a nurse as seen by parents of children hospitalized in the oncology department. Pol J Public Health. 2015; 4: 205-210.

16. Kojder E., Zarzycka D. Wizerunek zawodowy pielęgniarki i jego determinanty. Piel XXI w. 2014; 2(47): 47-52.

17. Leszczyńska M, Krajewska-Kułak E, Łukaszuk C, Sobolewski M, Kędziora-Kornatowska K, Borzuchowska A. Opinia pacjentów o jakości usług podstawowej opieki zdrowotnej na terenie miasta Jasła i jego okolic. Probl Hig Epidemiol. 2007; 88(3): 277-285.

Artykuł przyjęty do redakcji: 15.09 .2016

Artykuł przyjęty do publikacji: 03.02.2017

Źródło finansowania: Praca nie jest finansowana z żadnego źródła. Konflikt interesów: Autorzy deklarują brak konfliktu interesów.

\author{
Adres do korespondencji: \\ Marta Siwek \\ ul. Tumlińska 11 \\ 26-085 Miedziana Góra \\ tel.: 730101109 \\ e-mail: martasiwek8@gmial.com \\ Instytut Zdrowia Publicznego \\ Uniwersytet Jana Kochanowskiego w Kielcach
}




\title{
DOKONANA W PERSPEKTYWIE TEORII DYSTYNKCJI PIERRE'A BOURDIEU ANALIZA EMPIRYCZNA ZACHOWAŃ PODEJMOWANYCHWWOLNYM CZASIEPRZEZ PIELEGNIARKI IPOŁOŻNE
}

\section{EMPIRICAL ANALYSIS OF NURSES' AND MIDWIVES' LEISURE TIME BEHAVIOURS IN THE LIGHT OF PIERRE BOURDIEU'S THEORY OF DYSTHYMIA}

\author{
Grzegorz Konieczny ${ }^{1}$, Renata Rasińska² \\ ${ }^{1}$ Katedra Marketingu i Zarządzania \\ Wyższa Szkoła Hotelarstwa i Gastronomii w Poznaniu \\ ${ }^{2}$ Zakład Organizacji i Zarządzania w Opiece Zdrowotnej \\ Uniwersytet Medyczny im. Karola Marcinkowskiego w Poznaniu
}

DOI: https://doi.org/10.20883/pielpol.2017.67

\section{STRESZCZENIE}

Wstęp. Jak zauważają socjologowie sportu i przedstawiciele nauk o kulturze fizycznej, korzystanie z różnorodnych form sportu i rekreacji w czasie wolnym wydaje się jednym z najistotniejszych współczesnych obszarów badań społecznych, w których aplikować można klasową teorię Pierre'a Bourdieu.

Cel. Celem opracowania było nakreślenie w kontekście teorii dystynkcji autorstwa Pierre'a Bourdieu aktywności sportowo-rekreacyjnej pielęgniarek i położnych.

Materiał i metody. Badaniami objęto 127 zawodowo czynnych pielęgniarek i położnych pracujących w szpitalach oraz przychodniach POZ znajdujących się z terenie województwa wielkopolskiego. W pracy wykorzystano metodę sondażu diagnostycznego zrealizowanego za pomocą narzędzia, jakim był autorski kwestionariusz ankiety, wspomagany wywiadem nieustrukturyzowanym. Wyniki. Badane kobiety najczęściej preferują jazdę na rowerze, nordic walking, gimnastykę i ćwiczenia w domu, biegi, pływanie, aerobik, sporty zimowe oraz gimnastykę odchudzającą. Sprawność fizyczna oraz dobra kondycja często są rudymentami dla osób wykonujących zawód pielęgniarki i położnej. Potrzeby estetyczne to kolejny obszar lokujący się wśród istotnych wartości wynikających z uczestnictwa w aktywności sportowo-rekreacyjnej.

Wnioski. Uzyskane dane dotyczące aktywności sportowo-rekreacyjnej pielęgniarek i położnych pozwalają stwierdzić, że wybierane przez nie formy aktywności ruchowej mogą być dyskretnymi, ale ważnymi wyróżnikami ich stylu życia lub - idąc tokiem myślenia francuskiego socjologa Pierre’a Bourdieu - cechami społecznie dystynktywnymi.

SŁOWA KLUCZOWE: czas wolny, teoria dystynkcji Pierre'a Bourdieu, pielęgniarki, położne.

„Czas jest łagodnym bóstwem”. Być może był, dla nich. My uczyniliśmy z niego bożka szybkości. Umiesz zwolnić? Spróbuj! Pamiętaj, że wolny czas to przede wszystkim stan twojego umysłu! Nie sprzedawaj tego za byle co!!! Myśl starożytnych Greków

\begin{abstract}
Introduction. As the sociologists of sport and the representatives of physical culture observe, the consumption of various forms of sport and leisure activities seems to be one of the most important contemporary social research areas in which the Bourdieu's class theory can be applied.

Aim. The aim of the study was to outline the sports and recreational activities of nurses and midwives in the context of Pierre Bourdieu's class theory.

Material and methods. The study involved 127 professionally active nurses and midwives working in hospitals and outpatient clinics located in Wielkopolska province. The paper used the method of a diagnostic survey carried out using the tool, which was the author's questionnaire survey, assisted by an unstructured interview.

Results. Respondents prefer cycling, Nordic walking, gymnastics and home gymnastics, running, swimming, aerobics, winter sports and slimming gymnastics. Physical fitness is often rudimentary for nurses and midwives. The aesthetic needs are another area, located among the significant values resulting from participation in sport and recreation activities.

Conclusions. The obtained data on sports and leisure activities of nurses and midwives show that the forms of physical activity they choose may be discrete but important distinguishing features of their lifestyle or in the thinking of the French sociologist Pierre Bourdieu the socially distinctive features.
\end{abstract}

KEYWORDS: leisure, Pierre Bourdieu's refinement theory, nurses, midwives.

\section{Wstęp}

Zamierzeniem badawczym - podążając za ustaleniami jednego z czołowych przedstawicieli myśli społecznej drugiej połowy XX wieku, francuskiego socjologa Pier- 
re'a Bourdieu - było nakreślenie w szerszym, zhierarchizowanym kontekście strukturalnym (klasy społeczne) aktywności sportowo-rekreacyjnej pielęgniarek i położnych. Koncepcja Bourdieu dotycząca dystynkcji stała się dla autorów inspiracją do rozważań o zachowaniach podejmowanych w wolnym czasie przez pielęgniarki i położne. Na tą ciekawą i oryginalną koncepcję teoretyczną Bourdieu składa się specyficzna konstrukcja pojęciowa, obejmująca m.in. takie czynniki, jak: niezwykle złożone pojęcie habitusu, kapitał kulturowy, przemoc symboliczną oraz pole społeczne, jakim jest w tym przypadku pole aktywności sportowo-rekreacyjnej badanych kobiet realizowane w czasie wolnym. Powyższa konstrukcja pojęciowa nie tylko nadaje powagi podjętemu przedsięwzięciu badawczemu, lecz przede wszystkim dostarcza badaczowi takiej aparatury językowej, dzięki której może on głębiej wniknąć w wolnoczasową rzeczywistość, a przez to osiągnąć w pełni zamierzony cel badawczy.

Ponadto, jak zauważają socjologowie sportu i przedstawiciele nauk o kulturze fizycznej, korzystanie z różnorodnych form sportu i rekreacji w czasie wolnym wydaje się jednym z najistotniejszych współczesnych obszarów badań społecznych, w których aplikować można klasową teorię Bourdieu.

Zgodnie z koncepcją P. Bourdieu autorzy niniejszego opracowania rozpatrują przestrzeń społeczną aktywności sportowo-rekreacyjnej pielęgniarek i położnych jako dynamiczną rzeczywistość, jako pole, w którym agensi (działające pielęgniarki i położne) tworzą i odtwarzają praktyki związane z szeroko rozumianą kulturą fizyczną. Nie czynią tego jednak całkowicie swobodnie i intencjonalnie, a nawet nie w pełni świadomie, gdyż mając zinterioryzowane struktury świata społecznego w postaci ucieleśnionych dyspozycji (ze szczególnym uwzględnieniem aktywności sportowo-rekreacyjnej), są przez nie warunkowane [1]. Potwierdza to sam Bourdieu, stwierdzając, że pole nie jest wynikiem swobodnej twórczości i musi być posłuszne regułom czy lepiej prawidłowościom, które nie są ujawnione i skodyfikowane [2].

W obrębie pola społecznego toczy się permanentne współzawodnictwo (rozgrywka) symboliczne, wykorzystując potencjał lokujący się w określonych dla omawianego pola formach kapitału. Stawką w rywalizacji (współzawodnictwie), która toczy się w polu aktywności sportowo-rekreacyjnej, mogą być m.in. pożytki fizyczne (zdrowie, piękno, sprawność fizyczna, bądź niewidoczne, jak w przypadku higieny itd.), dalej pożytki generowane na samym ciele (np. smukłość, opalenizna, mniej lub bardziej wydatna muskulatura itd.) czy też ograniczony dostęp do wysoko selektywnych grup, który pewne praktyki otwierają (golf, polo itd.) [3]. Powyższe wskaźniki stanowią differentia specifica, czyli ujmując to w konwenanse Bourdieu - wartość dystynktywną dla pielęgniarek i położnych. Ponadto działania podejmowane na tym polu aktywności ruchowej mogą utwierdzać daną pozycję jednostki bądź grupy w innych polach, np. rodzinnym bądź zawodowym.

Konstrukt teoretyczny dotyczący teorii dystynkcji i poszczególnych jego składowych, jakimi są: habitus, kapitał, przemoc symboliczna oraz pole społeczne, został omówiony we wcześniejszym opracowaniu. Autorzy zachęcają czytelnika do zapoznania się z zaprezentowanymi tam teoretycznymi rozważaniami dotyczącymi powyższej kwestii. W tym artykule przedstawione zostaną teoretyczne refleksje dotyczące istoty i wpływu czasu wolnego na rzeczywistość społeczną człowieka.

Na wstępie rozważań warto nadmienić, że istnieje pewien paradoks w kwestii współczesnego czasu wolnego; pomimo że oszczędzamy go, mamy go coraz więcej, to jednak z dostępnych statystyk wynika, że stale go nam brakuje. Tezę tę podziela m.in. francuski socjolog J. Viard, autor książki Przeklęty wolny czas (Le Sacre du temps libre). Policzył on, że w ciągu ostatnich 100 lat czas trwania ludzkiego życia wydłużył się średnio z 500 do 700 tysięcy godzin. Czas pracy zaś z 200 tysięcy godzin zmniejszył się do zaledwie 67 tysięcy. "Inaczej mówiąc - pisze Viard na łamach pisma „Nouvelle Observateur” - praca, która w epoce Karola Marksa pochłaniała aż 40 procent ludzkiego życia, dziś zajmuje mniej niż 10 procent. llość wolnego czasu wzrosła. W 1900 roku przeciętny robotnik miał go w ciągu życia 100 tysięcy godzin. Dziś - cztery razy tyle, a mimo to stale brakuje nam czasu" [4].

Czas wolny jest obecnie zjawiskiem złożonym i wieloaspektowym, jak również niezmiernie istotną wartością psychofizyczną współczesnego człowieka, dotkniętego często nadmiarem obowiązków tak zawodowych, jak i domowych. Problematyka czasu wolnego istnieje w dyskursie publicznym, skutkiem tego są coraz to nowe publikacje - o charakterze interdyscyplinarnym - pojawiające się na rynku wydawniczym. Analizowana kategoria kształtowała się na przestrzeni wieków i niemal zawsze ukazywana była przeciwstawienie wobec kategorii pracy. Jak słusznie konstatuje G. Toti, każde państwo ma swój własny sposób na określenie czasu wolnego. Angielski termin to leisure, we Francji - loisir, w Stanach Zjednoczonych - free time, we Włoszech - tempo libero, a w Niemczech - freizeit. Z kolei starożytni Grecy używali wyrażenia schole na określenie czasu oznaczającego m.in. przerwę, odpoczynek czy też próżnowanie [5]. Literatura przedmiotu wskazuje, iż kategoria ta jest analizowana w różnych często jakże ambiwalentnych perspektywach teoretycznych. Istnieją koncepcje kładące nacisk na inny aspekt tego wycinka rzeczywistości społecznej. I tak, niektóre teorie głoszą 
tezę, że czas wolny ,z powodu swojej nikłej wartości stanowi jedynie uboczny aspekt pracy rozumianej w koncepcji teologicznej jako błogosławieństwo" [6]. W ujęciu marksistowskim pojęcie to odnosiło się do czasu, w którym człowiek doskonalił własną osobowość głównie po to, aby zyskać warunki dla radykalnych przeobrażeń procesu pracy i nowoczesnej produkcji [7]. Z kolei odmienne stanowisko prezentuje J. Tischner, zakładając, że czas przeznaczony na wypoczynek jest celem życia, praca zaś stanowi jedynie środek umożliwiający jego zdobycie i wypełnienie interesującą treścią [8]. Jeszcze inne rozważania traktują kategorię czasu wolnego i pracy jako komplementarne i równouprawnione, koherentne składowe ludzkiej egzystencji. Taki pogląd wyraża m.in. E. Kozak, stwierdzając, że zachowania podejmowane w wolnym czasie oraz praca to wzajemnie wzbogacające się części całościowej aktywności ludzkiej [9].

Z zaprezentowanych rozważań wynika, że ,...ze względu na sposób, w jaki człowiek kształtuje w swoim życiu relacje pomiędzy pracą a wypoczynkiem, można wyróżnić trzy wzorce: pierwszeństwo pracy, pierwszeństwo wypoczynku oraz komplementarność pracy i czasu wolnego" [10].

Za prekursora definicyjnego ujęcia czasu wolnego można uznać amerykańskiego ekonomistę i socjologa T. Veblena, który w ostatnich latach XIX wieku zdefiniował i wprowadził do literatury przedmiotu pojęcie czasu wolnego. Z zaproponowanej definicji wynika, że jest to czas obejmujący całokształt życia człowieka poza pracą, a ilość tego czasu decyduje o przynależności do klasy pracującej lub uprzywilejowanej [11]. Takie zwerbalizowanie jednej z najistotniejszych kategorii ludzkiej egzystencji, pomimo że znalazło liczną grupę zwolenników i było punktem odniesienia dla innych badaczy, to jednak nie uniknęło krytyki związanej z pojawiającą się w tej definicji dwuznacznością interpretacyjną (dotyczy ona istoty rozumienia tego terminu). Konstatacja taka wydaje się w pełni uprawniona w świetle analizy literatury przedmiotu, z której wynika, że istnieją dwie płaszczyzny, na których można rozpatrywać to zjawisko. Pierwsza to obszar swobody, w którym człowiek jest wolny jedynie od pracy zarobkowej, druga z kolei odnosi się do wolności nie tylko od pracy, ale m.in. od obowiązków rodzinnych czy też społecznych; jest to czas całkowitej swobody działań; czas, który można uznać za prawdziwie wolny.

Powracając jednakże do meritum, należy zauważyć, że czas wolny w dzisiejszym społeczeństwie jest istotnym wskaźnikiem jakości życia lub, posługując się Bourdieuowską formą wyrazową, „... jest wartością dystynktywną, statusową i prestiżową" [3]. Ponadto warto nadmienić, że czas wolny, jak wskazują J. Clarke i Ch. Critcher, pomimo że podlega procesowi komercjalizacji ,,...jest dobrem społecznym, wypracowanym przez jednostkę i społeczeństwo dla regeneracji sił fizycznych i psychicznych po pracy zawodowej, dla nauki, dla rozwijania indywidualnych zamiłowań i zainteresowań, zapewnienia kulturalnego wypoczynku i kształtowania bogatszej osobowości jednostki" [12].

Za najpełniejszą i mającą częste zastosowanie w międzynarodowych badaniach nad czasem wolnym uznaje się przyjętą przez UNESCO w 1957 roku definicję zaproponowaną przez francuskiego socjologa J. Dumazediera, który stwierdza, że „Czas wolny jest zespołem zajęć, którym jednostka może oddawać się z własnej woli bądź dla odpoczynku, bądź dla rozrywki, bądź dla rozwoju swych wiadomości lub bezinteresownego kształcenia się, względnie dla swego dobrowolnego uczestnictwa w życiu społecznym, po wyzwoleniu się od obowiązków zawodowych, rodzinnych i społecznych" [13].

Teoretyczne rozważania na temat czasu wolnego, który wpisuje się w teorię dystynkcji P. Bourdieu, zakończmy następującą konstatacją: kategoria, jaką jest czas wolny, może być analizowana z wielu perspektyw teoretycznych, które - jak przedstawiono - w odmienny sposób tłumaczą to zjawisko. Każda z nich kładzie nacisk na inny aspekt rzeczywistości społecznej. Perspektywy te można uznać za komplementarne, gdyż czas wolny jest zjawiskiem społecznym tak złożonym, że można je lepiej zrozumieć, jeśli patrzy się na nie z wielu perspektyw, i pomimo że czas wolny jest ,,bezproduktywny z ekonomicznego punktu widzenia - jego dystynktywna wartość nadal pozostanie w mocy" [3].

Z zaprezentowanej perspektywy spójrzmy poniżej na wyróżniki (znaczniki), jakimi są podejmowane - przez pielęgniarki i położne - formy aktywności sportowo-rekreacyjnej.

\section{Cel pracy}

Zgodnie z przyjętymi założeniami badawczymi celem opracowania było nakreślenie - w kontekście teorii dystynkcji autorstwa Pierre'a Bourdieu - aktywności sportowo-rekreacyjnej pielęgniarek i położnych. W ramach tego przedsięwzięcia autorzy dokonają próby przedstawienia preferowanych przez respondentki ww. form aktywności ruchowej, częstotliwości oraz jej znaczenia w wymiarze aksjologicznym dla respondentek.

\section{Materiał i metody}

Badaniami objęto 127 zawodowo czynnych pielęgniarek i położnych pracujących w szpitalach oraz przychodniach POZ znajdujących się z terenie województwa wielkopolskiego (w Poznaniu, Wrześni, Lesznie oraz Puszczykowie). Badania zostały przeprowadzone w grudniu 2016 roku. Badaną grupę stanowiło 81 pielęgniarek oraz 46 położnych. 
Problematyka badań nad zjawiskiem stratyfikacji społecznej, jak również aktywności sportowo-rekreacyjnej sytuuje się w nurcie badań diagnostycznych, dlatego wykorzystano metodę sondażu diagnostycznego zrealizowanego za pomocą narzędzia, jakim był autorski kwestionariusz ankiety, wspomagany wywiadem nieustrukturyzowanym. Udział badanych osób był dobrowolny oraz anonimowy. Respondentki zostały poinformowane o celu badania i wykorzystaniu ich kwestionariuszy z odpowiedziami na potrzeby niniejszego opracowania.

\section{Wyniki badań}

Spoglądając na ustalenia poczynione w obszarze cech demograficznych i wykształcenia pielęgniarek i położnych, stwierdzić można, że respondentki wpisują się w tzw. open data, obejmujący wskaźniki kwantytatywne, a w przypadku wykształcenia nieco je przewyższają.

Dominującą kategorię wśród badanych kobiet stanowią pielęgniarki w przedziale wiekowym 46-55 lat oraz 36-45 lat (odpowiednio: 35,0\% i 25,0\% ogółu respondentek). Kobiety w wieku 26-35 lat stanowiły $21 \%$ badanych, a w wieku 18-25 - tylko 13\%. Najmniej liczną grupę wiekową stanowią kobiety powyżej 56 . roku życia (6,0\% wskazań).

Z kolei dane procentowe w zakresie wykształcenia wskazują, że 97,0\% badanych kobiet posiada dyplom ukończenia studiów licencjackich, a 7,0\% respondentek deklaruje ukończone studia magisterskie.

Już same wskaźniki kwantytatywne w obszarze częstotliwości podejmowanych przez respondentki praktyk sportowo-rekreacyjnych z wysokim stopniem asercji postrzegane mogą być jako cechy społecznie dystynktywne, tj. wytwarzające wartość elitarną i prestiżową. Z uzyskanych danych wynika, że co druga badana osoba (50\%) codziennie lub kilka razy w tygodniu korzysta z różnych form aktywności sportowo-rekreacyjnych, a tylko 3,0\% pielęgniarek i położnych deklaruje, że nie uczestniczy w ww. formach. Powyższe dane przemawiają na korzyść badanej grupy, czyniąc ją tym samym społecznie dystynktywną.

Jak wynika z literatury przedmiotu, inne grupy zawodowe nie tak często podejmują aktywność w szeroko rozumianej kulturze fizycznej (por. Nowocień 1996, R. Winiarski 1997, R. Klementowski i wsp. 2000, B. Pachnowska 2001, A. Nowak 2002, M. Lipowski 2005, Eurobarometr 2013, Ministerstwo Sportu i Turystyki 20132015).

Kolejną kwestią w polu badawczym niniejszego opracowania była próba uzyskania odpowiedzi na pytanie dotyczące podejmowania najpopularniejszych form sportowo-rekreacyjnych przez respondentki w czasie wolnym. Okazuje się, że badane kobiety najczęściej preferują jazdę na rowerze, nordic walking, gimnastykę i ćwiczenia w domu, biegi, pływanie, aerobik, sporty zimowe oraz gimnastykę odchudzającą.

Z kolei w takich sportach, jak: wspinaczka skałkowa, żeglarstwo oraz zwielokrotniony maraton uczestniczy zaledwie kilka procent respondentek. Jednocześnie niewielka grupa kobiet (3\%) nie podejmuje żadnej formy aktywności sportowo-rekreacyjnej, tłumacząc to brakiem czasu spowodowanym nadmiarem obowiązków zawodowych i domowych. Zestawienie dotyczące powyższych wielkości przedstawiono w tabeli 1.

Tabela 1. Preferowane przez respondentki formy sportowo-rekreacyjne Table 1. Sports and recreation forms preferred by respondents

\begin{tabular}{ccc}
\hline $\begin{array}{c}\text { Preferowane przez respondentki formy sportowo-rekreacyjne/ } \\
\text { Sports and recreation forms preferred by respondents }\end{array}$ & $\mathrm{n}$ & $\%$ \\
\hline Jazda na rowerze/Riding a bike & 79 & 62 \\
\hline Nordnic walking/Nordic walking & 64 & 50 \\
\hline Gimnastyka i ćwiczenia w domu/Exercising at home & 59 & 46 \\
\hline Biegi//Jogging & 51 & 40 \\
\hline Pływanie/Swimming & 37 & 29 \\
\hline Aerobik/Aerobics & 33 & 26 \\
\hline Sporty zimowe/Winter sports & 31 & 24 \\
\hline Gimnastyka odchudzająca/Slimming exercising & 25 & 20 \\
\hline Pilates/Pilates & 23 & 18 \\
\hline Cardio\&muscle/Cardio\&muscle & 22 & 17 \\
\hline Wspinaczka skałkowa/Rock climbing & 10 & 8 \\
\hline Żeglarstwo/Sailing & 9 & 7 \\
\hline Zwielokrotniony maraton/Multiplied marathon & 3 & 2 \\
Nie podejmuję// do not take up & 6 & 5 \\
\hline
\end{tabular}

Źródło: badania własne. Dane nie sumują się do 100\%, ponieważ respondentki mogły wymienić więcej niż jedną odpowiedź Source: Author's own research. Data do not sum up to $100 \%$ as respondents were able to give more than one answer

Analizując kwestie aksjologiczne przedstawione w tabeli 2, należy stwierdzić, że $28,0 \%$ badanych podejmuje ww. formy aktywności ruchowej, widząc w nich przede wszystkim zdrowotne aspekty, tzn. utrzymanie dobrego stanu zdrowia. Z narracji respondentek wynika także, że satysfakcja z utrzymania w wysokim stopniu sprawności fizycznej jest drugą z kolei wartością niezmiernie ważną. Na kategorię tę wskazuje 20,0\% kobiet. Warto nadmienić, że sprawność fizyczna oraz dobra kondycja często są rudymentami dla osób wykonujących zawód pielęgniarki i położnej. Potrzeby estetyczne to kolejny obszar (dla 12,0\% badanych kobiet) lokujący się wśród istotnych wartości wynikających z uczestnictwa w aktywności sportowo-rekreacyjnej. 
Tabela 2. Wartości wynikające z uczestniczenia w aktywności sportowo-rekreacyjnej

Table 2. Values resulting from participation in sports and recreation activity

\begin{tabular}{|c|c|c|}
\hline $\begin{array}{c}\text { Wartości wynikające z uczestniczenia w aktywności sportowo- } \\
\text { rekreacyjnej/Values resulting from participation in sports and } \\
\text { recreation activity }\end{array}$ & $\mathrm{n}$ & $\%$ \\
\hline $\begin{array}{l}\text { Zdrowotne znaczenie rekreacji ruchowej pozwalające na utrzy- } \\
\text { manie dobrego stanu zdrowia/Health meaning of physical recre- } \\
\text { ation enabling to keep a good state of health }\end{array}$ & 45 & 35 \\
\hline $\begin{array}{c}\text { Satysfakcja wynikająca ze sprawności fizycznej/Satisfaction } \\
\text { fesulting from physical fitness }\end{array}$ & 32 & 26 \\
\hline Potrzeby estetyczne/Aesthetic needs & 27 & 21 \\
\hline Poprawa samopoczucia/Mood improvement & 18 & 14 \\
\hline $\begin{array}{l}\text { Umożliwienie pozytywnego rozładowania napięć psychofizycz- } \\
\text { nych/Enabling positive discharge of psychophysical tensions }\end{array}$ & 19 & 15 \\
\hline $\begin{array}{l}\text { Wartości hedonistyczne, np. przyjemność/Hedonistic values, } \\
\text { e.g. pleasure }\end{array}$ & 9 & 7 \\
\hline $\begin{array}{l}\text { Kształtowanie motywacji do zachowań prozdrowotnych/Shaping } \\
\text { motivation for prohealth behaviours }\end{array}$ & 12 & 9 \\
\hline
\end{tabular}

Źródło: badania własne. Dane nie sumują się do 100\%, ponieważ respondentki mogły wymienić więcej niż jedną odpowiedź

Source: Author's own research. Data do not sum up to $100 \%$ as respondents were able to give more than one answer

Na aspekt związany z estetyką zwrócił uwagę m.in. P. Bourdieu, kontstatując, że ,...kluczowym elementem systemu preferencji dyscyplin sportowych może być stosunek do ciała i to, w jaki sposób jest ono wykorzystywane w działaniu, co jest kojarzone z pozycją społeczną i wewnętrznym doświadczeniem rzeczywistości fizycznej i społecznej. Ten stosunek do ciała jest elementem ogólnego stosunku jednostki do świata: najbardziej wyróżniające praktyki sportowe to te, w których znajdujemy się w największym oddaleniu od przeciwnika; są one najbardziej estetyczne, przemoc jest w nich najmniej widoczna, a forma i technika zwycięża nad siłą i funkcjonalnością" [14].

Nie bez znaczenia dla respondentek jest także możliwość pozytywnego rozładowania napięć psychicznych, które w tym zawodzie są nieuchronne. Na tę kategorię jako istotną wartość wskazuje 12,0\% badanych kobiet. Z kolei wartości hedonistyczne oraz kształtowanie motywacji do zachowań prozdrowotnych eksponuje najmniej badanych, po 6,0\% wskazań dla obu kategorii.

\section{Wnioski}

Uzyskane dane dotyczące aktywności sportowo-rekreacyjnej pielęgniarek i położnych pozwalają stwierdzić, że wybierane przez nie formy aktywności ruchowej mogą być dyskretnymi, ale ważnymi wyróżnikami ich stylu życia lub - idąc tokiem myślenia francuskiego socjologa Pierre'a Bourdieu - cechami społecznie dystynktywnymi.
Podjęta w niniejszym opracowaniu problematyka ujęta w perspektywie teorii dystynkcji Pierre'a Bourdieu jest jednym z pierwszych głosów w dyskusji na temat aktywności sportowo-rekreacyjnej pielęgniarek i położnych.

1. Poddając analizie dane z powyższych tabel, należy stwierdzić, że spośród 127 badanych pielęgniarek i położnych 60,0\% z ogółu badanej populacji jest w przedziale wiekowym 36-55 lat.

2. Co druga badana osoba $(50 \%)$ codziennie lub kilka razy w tygodniu uczestniczy w różnych formach sportowo-rekreacyjnych.

3. Preferowanymi formami aktywności ruchowej są: jazda na rowerze, nordic walking, gimnastyka i ćwiczenia w domu, biegi, pływanie, aerobik, sporty zimowe, a także gimnastyka odchudzająca.

4. Rozpatrując kwestie aksjologiczne wynikające z systematycznego uczestnictwa w omawianych formach aktywności, istotnymi kwestiami - poniekąd motywatorami - są aspekty zdrowotne, dalej sprawność i dobra kondycja fizyczna oraz potrzeby estetyczne.

Domykając w tym miejscu ramy niniejszego opracowania, autorzy pragną podkreślić kilka ważnych kwestii, które są wynikiem przeprowadzonych analiz teoretyczno-badawczych.

Po pierwsze, czas wolny jako kategoria społeczna cechuje się dość znaczącą fluktuacją właściwości oraz podlega permanentnej ewolucji. Przeobrażenia te są ściśle związane z kontekstem społeczno-kulturowym, wręcz od niego zależne.

Po drugie, podjęty został ważny problem aktywności ruchowej w kontekście czasu wolnego. Rozważania obejmują m.in. postrzeganie, rozumienie i przeżywanie różnych form sportowo-rekreacyjnych.

Po trzecie, poruszana kwestia jest tym istotniejsza, że tzw. ideologia healthismu coraz bardziej jest uznawana i akceptowana.

Po czwarte, jak wynika z analiz literaturowych, w Polsce nie ma jeszcze ugruntowanej wiedzy i doświadczeń dotyczących wpływu szeroko rozumianego uczestnictwa w kulturze fizycznej na stratyfikację społeczną, tym niemniej, jak wynika z literatury przedmiotu, praktyki sportowo-rekreacyjne w czasie wolnym mogą być i są formą dystynkcji społecznych, a tym samym teoria klas francuskiego socjologa P. Bourdieu znajduje w tych analizach swoje uprawomocnienia. W związku z powyższym prezentowane zachowania podejmowane w wolnym czasie przez pielęgniarki i położne, rozumienie oraz intensywność tych zachowań są de facto składowymi stylu życia badanej grupy, a zarazem wyróżnikiem aktywności społecznej badanych; inaczej mówiąc, „... wytwarzają wartość dystynktywną, statusową i prestiżową" [3]. 


\section{Piśmiennictwo}

1. Por.: Mielczarek M. Inspiracje teorią Pierre'a Bourdieu w poradoznawstwie. Edukacja Dorosłych. 2015; 1: 62-63.

2. Bourdieu P, Wacquant L. Logika pól. W: Jasińska-Kania A, Nijakowski LM, Szacki J, Ziółkowski M (red.). Współczesne teorie socjologiczne. T. 2. Warszawa: Wyd. Nauk. Scholar; 2006. 652.

3. Za: Lenartowicz M. Klasowe uwarunkowania sportu z perspektywy teoretycznej Pierre'a Bourdieu. Kultura i Społeczeństwo. 2013; 3: 52, 61-62.

4. (Dostępne w Internecie:) http://www.rp.pl/artykul/862318Czasu-wolnego-naucznas-Panie.html\#ap-3 (data dostępu: 12.09.2016)

5. Por.: Toti G. Czas wolny. Warszawa: Książka i Wiedza; 1963. 68.

6. Por.: Nowacki T. Praca, jej wartość i znaczenie w indywidualnym życiu człowieka. Zielona Góra: WSP; 1988. 51.

7. Por.: Czajka S. Rewolucja naukowo-techniczna a kształcenie. Kwartalnik Pedagogiczny. 1972; 4.

8. Por.: Tischner J. Społeczność, która nie wojowała myślą. Tygodnik Powszechny. 1997; 9.

9. Kozak E. Miejsce wypoczynku wśród zajęć ucznia klasy piątej i jego środowiskowe uwarunkowania. Kraków: Impuls; 2004. 15.

10. Por.: Strzemińska H. Współczesne poglądy na czas wolny ludzi niepełnosprawnych - zadania pedagoga. W: Hulek A (red.). Studia Pedagogiczne LX. Wrocław: Ossolineum; 1989. 79.
11. Za: Czajka Z. Z problemów czasu wolnego. Warszawa: CRZZ; 1974. 38.

12. Czajkowski K. Wychowanie do rekreacji. Warszawa: WSiP; 1979. 10.

13. Za: Łukawska A. Nauka i czas wolny uczniów szkół podstawowych i średnich. Kraków: Wyd. Uniwersytetu Jagiellońskiego; 1991. 162.

14. Bourdieu P. Sociology in Question. London: Sage Publications; 1995. 157.

Artykuł przyjęty do redakcji: 12.10.2016

Artykuł przyjęty do publikacji: 25.11.2016

Źródło finansowania: Praca nie jest finansowana z żadnego źródła. Konflikt interesów: Autorzy deklarują brak konfliktu interesów.

\author{
Adres do korespondencji: \\ Renata Rasińska \\ ul. Mariana Smoluchowskiego 11 \\ 60-179 Poznań \\ tel.: 618612254 \\ e-mail: rasinska@ump.edu.pl \\ Zakład Organizacji i Zarządzania w Opiece Zdrowotnej \\ Uniwersytet Medyczny im. Karola Marcinkowskiego w Poznaniu
}

